\title{
Developing Countries in the Global E conomy: A Forward Looking View
}

\author{
John Whalley
}

CSGR Working Paper No. 36/ 98

July 1999
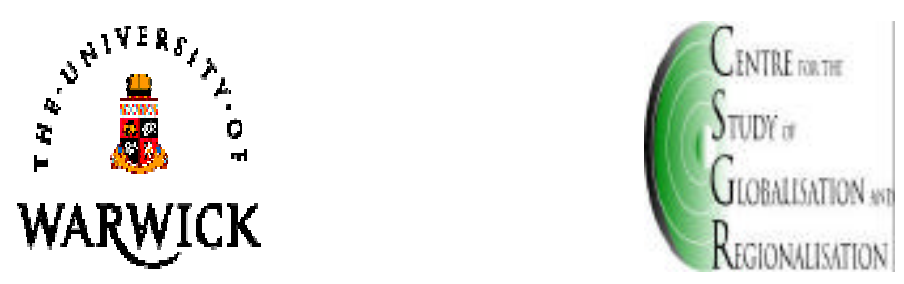

E.S.R. C
ECONOMIC
\& SOCIAL
RESEARCH
COUNCIL 


\title{
Developing Countries in the Global Economy: A Forward Looking View John Whalley ${ }^{1}$ University of Warwick, Western O ntario and NBER CSG R Working Paper No. 36/ 99 \\ July 1999
}

\begin{abstract}
:
This paper discusses what the next few decades could bring for the developing countries in terms of the size and composition of their trade and inward investment flows, as well as a possibly changing policy framework within the global economy in which they have to operate. Both the prospects and implications are clearly different from country to country, but given the breadth of the paper the focus is more on impacts on groups of countries rather than on specific countries.

The bottom line of the paper, is a cautious one. Three nagging questions are repeatedly re-emphasized. Can trade growth really be high enough on the import side in the OECD if now 100 or more developing countries see globalization and increased exports as their primary route to growth, industrialization, and development. Can barrier reductions in OECD markets and future WTO negotiations be relied on to fuel this, as in the past; and is there a more sinister scenario that new barrier increases could even choke off some of the trade growth? And what is to happen to development strategies if this course fails, as it seemingly has done so already for the low income countries? Having posed these questions, there are bright spots; the more rapid growth of South-South trade, even more rapid growth of least-developed to mid-developed country trade; higher growth rates of FDI than trade, and more and more developing country trade being investment driven. The papers' overriding message is perhaps that the world is not static, and country strategies toward the global economy need to reflect this.
\end{abstract}

Keywords: Developing Countries, global Economy, Trade, Globalization

Address for correspondence:

John Whalley

Centre for the Study of Globalisation and Regionalisation,

University of Warwick,

Coventry CV4 7AL,

United-Kingdom

\footnotetext{
${ }^{1}$ This is a revised draft of a paper prepared for a workshop November 16th and 17th 1998 in New York on Globalization held under the auspices of the UN Human Development Report. I am grateful to Sakiko Fukuda-Parr and Pablo Rodas-Martin for helpful comments.
} 


\section{Non-Technical Summary}

This paper discusses what the next few decades could bring for the developing countries in terms of the size and composition of their trade and inward investment flows, as well as a possibly changing policy framework within the global economy in which they have to operate. Both the prospects and implications are clearly different from country to country, but given the breadth of the paper the focus is more on impacts on groups of countries rather than on specific countries.

Assuming a recovery from the current financial turbulence over a period of three to five years, however, questions will still remain about how developing country participation in the global economy in the decade beyond will develop. Can developing country involvement in the global economy accelerate further; can their trade shares in developed country markets grow yet more, and for each exporter? Is there a fallacy of composition involved, that with initially only a few countries being able to successfully pursue an outward oriented strategy as against the 100 or some countries now that are attempting to do so, the increases in aggregate import volumes into the OECD markets cannot support success for all these countries? Can the growth of their trade perhaps be fuelled by more rapidly growing south-south trade as more and more developing countries achieve higher levels of income in a recovery phase, or for now does this remain too small? Equally, while investment flows into developing country markets have accelerated in the pre-crisis period they remain concentrated, being particularly in Asia and heavily so in China. Is breaking away from this concentration is a further key element in a strategy for broadening trade and income growth in the developing world. 
The bottom line of the paper, is a cautious one. Three nagging questions are repeatedly reemphasized. Can trade growth really be high enough on the import side in the OECD if now 100 or more developing countries see globalization and increased exports as their primary route to growth, industrialization, and development. Can barrier reductions in OECD markets and future WTO negotiations be relied on to fuel this, as in the past; and is there a more sinister scenario that new barrier increases could even choke off some of the trade growth? And what is to happen to development strategies if this course fails, as it seemingly has done so already for the low income countries? Having posed these questions, there are bright spots; the more rapid growth of SouthSouth trade, even more rapid growth of least-developed to mid-developed country trade; higher growth rates of FDI than trade, and more and more developing country trade being investment driven. The papers' overriding message is perhaps that the world is not static, and country strategies toward the global economy need to reflect this.

The paper first discusses developing country trade performance in recent years, highlighting its rapidly changing size and composition. It then moves to a discussion of the policy framework for future trade growth, including the prospects for a WTO Millennium Round. It concludes with a discussion of developmental strategies for developing countries that rely on their increasing integration into the global economy 


\section{Introduction and Background}

This paper discusses what the next few decades could bring for the developing countries in terms of the size and composition of their trade and inward investment flows, as well as a possibly changing policy framework within the global economy in which they have to operate. Both the prospects and implications are clearly different from country to country, but given the breadth of the paper the focus is more on impacts on groups of countries rather than on specific countries.

In the shorter term the influence of the current financial crises on previous strong trade performance is a concern, especially in Asia, although the positive exchange rate effects on the export side should eventually lead to even more elevated trade performance, assuming no major recession in the OECD. On the other hand countries concerned by the large adjustments costs they face when excess volatility in global financial markets also affects their own economy, ${ }^{1}$ and typified by Malaysia, are tightening their foreign exchange and investment regimes and this may limit their capital inflows and slow trade growth, which, for several key countries over the last decade, has been closely linked to direct inward foreign investment.

Assuming a recovery from the current financial turbulence over a period of three to five years, however, questions will still remain about how developing country participation in the global economy in the decade beyond will develop. Can developing country involvement in the global

\footnotetext{
${ }^{1}$ Rodrick (1998) also emphasizes the adjustment consequences more broadly from globalization.
} 
economy accelerate further; can their trade shares in developed country markets grow yet more, and for each exporter? Is there a fallacy of composition involved, that with initially only a few countries being able to successfully pursue an outward oriented strategy as against the 100 or some countries now that are attempting to do so, the increases in aggregate import volumes into the OECD markets cannot support success for all these countries? Can the growth of their trade perhaps be fuelled by more rapidly growing south-south trade as more and more developing countries achieve higher levels of income in a recovery phase, or for now does this remain too small? Equally, while investment flows into developing country markets have accelerated in the pre-crisis period they remain concentrated, being particularly in Asia and heavily so in China. Is breaking away from this concentration is a further key element in a strategy for broadening trade and income growth in the developing world.

Independently of whether this accelerating trade performance can continue the unevenness of impact of global developments on individual developing countries and the marginalization which has affected the lower income countries, and particularly the poorer and smaller countries in Sub Saharan Africa is an issue. ${ }^{2}$ These countries remain almost exclusively as commodity exporters; some have export revenues equal to only a small fraction of import costs, with the balance financed by aid flows (Mozambique is such an example). While many of these countries have been affected by political problems, civil unrest, and macro economic mismanagement, as

\footnotetext{
${ }^{2}$ See the discussion of an African country's interests (Kenya) in the trading system in Mwega and Muga (1998). Also Armstrong and Read (1998) provide a recent discussion of the performance of smaller countries in the trading system.
} 
commodity prices have fallen they have experienced sharp declines in their trade shares as a fraction of overall world trade, with in some cases, absolute declines in trade in value terms. To these countries the outward oriented strategies pursued in Korea and Taiwan since the 1960's seems to be so far removed from their current situation as to be seemingly irrelevant. Diversification of trade is sometimes held out as the way forward, but how is this to be achieved? Is it really so simple as establishing a stable pro investment policy regime, and foreign investment will flow into these countries and trade will grow. At present, the core development strategy being offered by the World Bank and the IMF to such countries is policy reform, linked to opening of the external sector. But for the least developed countries, to place such a large bet on trade as the engine of their future growth seems extreme given their current situation. How to deal with the performance of the lowest income countries within the global framework of the next two decades is thus also a central concern.

The global policy environment which developing countries are likely to face in the global economy may also see sharp change from the past over the next twenty or thirty years. A potential new round of WTO trade negotiations, the Millennium Round, is widely mooted. Regional trade agreements may continue their spread across the globe, but regional conflict (as presently between the US and the EU over bananas) may grow. Particularly critical is that the reductions in trade barriers on manufactured products which have taken place in the OECD countries over the post-war years have, in the tariff area, reached levels for which significant further reductions are to all intents and purposes inconsequential, except for a few product 
concentrated tariffs, such as in textiles and apparel. The odds seem to be that trade barriers on manufactured goods against developing countries, with little further downside potential, may begin to go up rather than down; while barriers on agricultural products, long thought poor prospects for developing country exports may fall.

Key are also proposals which link increased trade barriers (sanctions) to developing country compliance with developed country policy objectives (including in environment and labour standards), and antidumping actions. The threat of increased trade barriers if compliance does not occur may increasingly be used to force countries to modify their domestic policies as Mexico experienced in their 1990 tuna dispute with the US. Thus, after fifty years of ever falling tariff barriers in developed country markets, the next thirty to forty years may well see pressures to raise barriers, fuelled in part by developed country political interests wanting protection against competing imports. These could be likely key issues in a future Trade Round that developing countries will have to deal with.

In addition to possible barrier increases, the developing countries may also face ever broadening WTO negotiations within the global trade policy framework. These will likely come on top of WTO Uruguay Round negotiations which have only just concluded, and with a complexity on which few countries are on top. Developing countries have been somewhat passive in their approach to the prospect of such negotiations, usually attempting to resist broadening, and trying to mitigate potential negative effects of any broadening that might occur. Broadening of this type occurred in the 1990's in the WTO in intellectual property, and threatens to grow even further 
over the next ten years in a new Millennium Trade Round into such areas as competition policy, environment, labour standards and investment.

But this changing policy framework is one which also offers opportunities for many countries. For instance, broadening the discussion of intellectual property rights negotiations to cover all forms of property rights, including those involved with environmental concerns (such as rights to emit carbon into the upper atmosphere) could yield significant gains for developing countries. If the argument were accepted that developed countries had largely used up their emission rights cumulatively over their period of industrialization and hence had to buy rights from individual developing countries, significant new flows of development assistance could result. In the environment area, one in which developing countries have long resisted trade linkage, it seems clear that countries with significant environmental assets (Indonesia, Malaysia, Thailand, Democratic Congo, Cameroon, Brazil for instance; countries with significant forest cover) have the capability to make significant concessions in order to achieve benefits in other areas such as trade and investment if they choose to use it. This is because they are the custodians of major environmental assets and globally have significant leverage in this area. Broadened negotiations is thus something that offers countries opportunities as well as threats. And countries without the environmental endowments to make larger concessions, if they are to be beneficiaries of a trade and environment bargain, may want to support such a bargain by making concessions to other developing countries. Increased South-South trade could even flow from such arrangements. 
Finally, there are the finance related issues of a global exchange rate regime in turmoil following the onset of financial crises, and the clear weakening of the position of the IMF on these matters. Formulating a developing country strategy for international financial arrangements over the next two decades would seem to be paramount. And more broadly, the Bretton Woods institutions themselves which were designed to deal with the problems of the 1940's are now coming under increasing stress and even re-examination as discussion of new global arrangements into the next century gets under way. Developing country participation in these discussions will be central, and prior to that a clear sense of what the developing country interests are in different options needs to be formulated.

The bottom line of the paper, however, is a cautious one. Three nagging questions are repeatedly re-emphasized. Can trade growth really be high enough on the import side in the OECD if now 100 or more developing countries see globalization and increased exports as their primary route to growth, industrialization, and development. Can barrier reductions in OECD markets and future WTO negotiations be relied on to fuel this, as in the past; and is there a more sinister scenario that new barrier increases could even choke off some of the trade growth? And what is to happen to development strategies if this course fails, as it seemingly has done so already for the low income countries? Having posed these questions, there are bright spots; the more rapid growth of South-South trade, even more rapid growth of least-developed to mid-developed country trade; higher growth rates of FDI than trade, and more and more developing country trade being investment driven. The papers' overriding message is perhaps that the world is not static, and country strategies toward the global economy need to reflect this. 
The paper first discusses developing country trade performance in recent years, highlighting its rapidly changing size and composition. It then moves to a discussion of the policy framework for future trade growth, including the prospects for a WTO Millennium Round. It concludes with a discussion of developmental strategies for developing countries that rely on their increasing integration into the global economy

\section{Developing Country Trade Performance In The Global Economy Trade-Led Development Strategies}

Over the last ten to fifteen years, more and more developing countries have placed a larger and larger bet on a development strategy of evermore integration by them into the global economy; a so called outward oriented strategy. In the 1950's the two countries which made this bet, Hong Kong and Taiwan (and a little later Korea), achieved spectacular results and their very success was influential from the mid 1980's on in persuading perhaps 100 or more other developing countries around the world that their future also lay in opening up their economies to trade and exploiting the opportunities which they saw as emanating from more involvement in with global economy. The late 1980's and early 1990's saw the most extensive and far reaching trade liberalization ever achieved globally, and it was undertaken unilaterally (not negotiated multilaterally) and by the developing countries.

However, not only have the financial crises of the last year raised the obvious question as to whether this strategy has proved to be a little naive in terms of the excess weight which it places on global involvement as the main development strategy, the bifurcated record (until the last year) 
of success by the high growth, larger and middle income developing countries (in Asia and Latin America) and the seeming poor trade and growth record and even marginalization of many low income countries, has also compounded such concerns. In the 1930's there was an active debate on whether trade was the engine or hand maiden of growth; a debate which in the 1990's has seemingly been lost in the assertion that it clearly is the engine. The experience of financial turbulence, and negative growth in marginalized low income countries revives that debate.

Accepting that in reality the developing countries are a heterogenous group of countries, they have gone through many several twists and turns over the last forty years in trying to decide upon their approach to trade related issues. And outside of Sub Saharan Africa and a smaller number of lower income non African countries, they have, in the main, been successful in raising the level of their participation in the global economy. Their exports of industrial products (especially from Asia) have soared, the higher GDP growth countries have been the rapidly growing exporters, and over 30 years the more successful of those adopting this strategy have seen a five fold increase in real income per capita.

In the 1950's they argued that their balance of payments problems made it impossible for them to liberalize their trade regimes, and facing ever declining terms of trade they argued that they should jointly seek preferential access to developed country markets without liberalizing in their own markets. This strategy, which was initially pursued as a common approach by all developing countries with the exceptions of Hong Kong and Taiwan (and later Korea), became identified 
with the slogan of "special and differential treatment". ${ }^{3}$ Through the middle of the 1980's most countries supported a bloc wide trade and development negotiating strategy, jointly emphasizing their need both to protect their own domestic markets and for preferential access to developed country markets.

In essence, the argument was that to grow developing countries needed both special treatment and insulation from the forces of globalization. In the 1970's, coincident with these lines of argumentation, developing country exports began to surge.

Beginning in the mid 1980's and reflecting growth generally in manufactured exports from Latin America and Asia, a number of developing countries began to change course and adopt a more open trade approach, focussing now on the need to liberalize to harness gains from trade and the long run welfare benefits from unilateral trade liberalization. These developments were driven by North America trained meritocrats first in Latin American countries and subsequently elsewhere, and were strongly supported by the World Bank and the IMF. Country after country in the midlate 1980's moved to deep unilateral liberalization, not only in trade, but in policies towards foreign investment. The result was a dramatic reduction in barriers to trade and inward capital flows in developing countries. Accompanying these changes were also clear movements away from a common blocwide negotiating position on global trade issues among developing countries, and towards pursuit of individual country interest even where this conflicted with other developing countries. Argentina, for instance, argued for global liberalization in grains and beef, and Thailand in rice, even if other net food importing countries, such as Egypt, were opposed on

\footnotetext{
${ }^{3}$ See the discussion in Whalley (1990).
} 
the grounds of wanting to remain as beneficiaries agricultural export subsidies from Europe.

The idea that a common blockwide position of special and differential treatment should be pursued as the pivotal developing country trade and development strategy has continued to weaken since the mid 1980's, and the strength of trade performance of developing countries has if anything, accelerated; at least up to the onset of the current financial crises. Thus putting on one side the marginalized lower income countries, developing country trade on the whole has showed remarkable gains over the last 40 years, even though the developing countries have vacillated in their approach to both trade negotiations and their own trade policies.

\section{Trade Performance}

Table 1 sets out the 1995 export, import, and FDI (foreign direct investment) performance of the group of developing countries as classified by UNCTAD, reporting imports and exports in 1995 dollars and as a percentage of all trade.

The term 'developing country' implies a uniformity across countries which in practice can be a little misleading. Income per capita levels range from highs in Asia of $\$ 20,000$ in the case of Singapore, to levels of $\$ 100$ in the case of Somalia and some of the lower income African

economies. And as emphasized in Whalley (1989) these differences in income levels are also accompanied by diversity in growth performance, trade patterns, degrees of industrialization, patterns of capital formation and social welfare systems. As a result, the developing countries are 
in reality a heterogenous group of countries which it is often difficult to discuss as if they were one single group.

The data in Table 1, despite this heterogeneity, indicate that developing countries now play a large and (until recently) growing role in the global economy, accounting for a little under $30 \%$ of world trade on both the import and export sides. Since exports of affiliated companies of foreign parents account for nearly $50 \%$ of developing country exports ${ }^{4}$, it follows that inward foreign investment flow to these countries are now a key factor underlying this trade. Foreign direct investment flows into the developing countries were perhaps 100 billion dollars in 1995, around $30 \%$ of worldwide direct foreign investment, although only small if not negligible flows ( 1 billion dollars) went to the least developed countries.

Table 1

\section{Trade and Investment Flows of the Developing Countries}

\begin{tabular}{|l|l|l|}
\hline & \$bill 95 & as \% of World \\
\hline Imports & 1,493 & $29.1 \%$ \\
\hline Exports & 1,406 & $27.7 \%$ \\
\hline FDI & 96.3 & $30.4 \%$ \\
\hline FDI Least Developed & 1.02 & $0.3 \%$ \\
\hline
\end{tabular}

Sources: UNCTAD (1997a) Tables 1.1, 1.2. UNCTAD (1997b) Table B.1.

\footnotetext{
${ }^{4}$ This estimate is discussed in more detail later.
} 


\section{Trade in Industrial Products}

Table 2 indicates developing country trade in industrial products, rather than in all products, of around 400 billion dollars on the export side, and a little over 200 billion dollars on the import side. Unlike two decades earlier, developing countries are now significant net exporters of industrial products, and it is these exports which have surged in recent years. Key to this performance have been low tariff barriers in OECD export markets, which now average around $2 \frac{1}{2} \%$ markets (with higher rates on some products such as textiles and apparel). Barriers remain on the import side in developing countries, although there has been substantial unilateral liberalization in these regions in the last few years. Average developing country trade barriers on industrial products post Uruguay Round average around 13 to $14 \%$, of which barriers at 20 to $25 \%$ levels apply to textiles and apparel, and around 20\% to imports of transportation equipment.

Table 2

\section{Developing Country Trade in Industrial Products and Tariff Barriers}

\begin{tabular}{|l|c|c|}
\hline & \$bill 94 \\
\hline $\begin{array}{l}\text { Developing Country Exports } \\
\text { of Industrial Products (94) }\end{array}$ & 433.2 \\
\hline $\begin{array}{l}\text { Developing Country Imports } \\
\text { of Industrial Products (94) }\end{array}$ & 229.4 & Bound \\
\hline \multicolumn{2}{|c|}{ Applied } & $3.5 \%$ \\
\hline $\begin{array}{l}\text { Average OECD tariff barriers } \\
\text { (post Uruguay Round) on }\end{array}$ & $2.5 \%$ & \\
\hline
\end{tabular}


13

\begin{tabular}{|c|c|c|}
\hline $\begin{array}{c}\text { industrial products: of which } \\
\text { Textiles/apparel } \\
\text { Transport equipment }\end{array}$ & $8.4 \%$ & $11.0 \%$ \\
& $4.6 \%$ & $5.6 \%$ \\
\hline $\begin{array}{l}\text { Average developing country } \\
\text { tariff barriers (post Uruguay } \\
\text { Round) on industrial } \\
\text { products: of which }\end{array}$ & $13.3 \%$ & \\
Textiles/apparel & $21.2 \%$ & $13.3 \%$ \\
Transport equipment & $19.9 \%$ & $25.5 \%$ \\
\hline
\end{tabular}

Sources: UNCTAD (1997a) Tables 3-1, A, 13

Laird (1998)

\section{Commodity Trade}

In contrast to industrial product trade, commodity based exports have been sharply falling as a share of overall developing country trade. In the 1950's developing countries' exports were largely of commodities such as rubber, coffee, cocoa, and metallic ores and other products for which there was no immediate competitor in developed country markets. As Table 3 indicates, as a fraction of all developing country exports, these accounted for perhaps $30 \%$ of the total in the 1990 's, whereas in the 1960's this figure was closer to $80 \%$.

Most commodity exports also continue to enter developed country markets free of barriers, because of the absence of immediately competing products. This is one reason lower income countries often see themselves as having little to gain from WTO trade negotiations. A central issue which has been repeatedly raised by them in this area over the last 30 years is that of tariff escalation. This reflects the concern in exporting countries that as attempts are made by them to 
upgrade their production through higher levels of fabrication, they have faced ever higher tariff barriers on final products. Even if there are low barriers against raw commodity exports, they argue that any attempt to export products produced from them encounters higher barriers.

Table 3 reports WTO estimates of tariff escalation in OECD markets against developing country commodity exports, showing effective barriers as high as $6 \%$ for higher stages of production, but also showing that Uruguay Round tariff barrier reductions have considerably reduced their quantitative impact. As a working hypothesis, the assumption that developing country exports of both commodities and their immediate fabricated products are restrained more by supply factors and bottlenecks rather than by trade barriers thus seems appropriate, and if this is the case domestic infrastructure and global prices are more important issues for exporting countries than global negotiations on trade barriers.

Commodity exports is also an area where there has been profound pessimism as to the pricing prospects for developing countries, which continues until today. The original Singer/Prebisch thesis of the 1950's argued that developing countries would always face a secular decline in their terms of trade for their commodity based exports. The argument was that commodities are basic items with low income elasticities in trade (necessities), while developing countries tend to import equipment and machinery (luxuries) based on high income elasticities. As a result, growth in the world economy with both rich and poor countries trying to simultaneously grow would depress the prices of commodities. In recent years, particularly in the post-crisis environment and also 
emphasized in the recent Trade and Development Report from UNCTAD, the pricing prospects for commodities are widely regarded as poorer than ever; again elevating concerns over marginalization of low income commodity exporting countries in the global economy. 
Table 3

\section{Commodity Based Trade of Developing Countries}

\begin{tabular}{|c|c|c|}
\hline & \$bill 94 & $\begin{array}{c}\text { As \% of All Developing } \\
\text { Country Exports }\end{array}$ \\
\hline $\begin{array}{l}\text { Value of Commodity Exports (including } \\
\text { fuel) of Developing Countries (94) }\end{array}$ & $\$ 383.5$ & 27.3 \\
\hline $\begin{array}{l}\text { Tariff Escalation and Commodity Exports } \\
\text { Against Tropical Products }\end{array}$ & Pre Uruguay Round & Post Uruguay Round \\
\hline Raw Materials & 0.1 & 0.0 \\
\hline Semi Finished & 6.3 & 3.5 \\
\hline Finished Goods & 6.6 & 2.6 \\
\hline
\end{tabular}

Source: UNCTAD (1997a) Table A.12.

GATT (1994)

\section{Agricultural Trade}

A further component of developing country trade is agricultural products for which data is set out in Table 4. Agricultural products are generally regarded as being the closest to autarchy in trade (a situation where countries consume largely what they produce), in part because of the barrier structure in global agricultural trade which precludes significant amounts of trade. As a result, potential exports of agricultural products by developing countries are large, particularly for countries such as Argentina and Brazil. But as Table 4 indicates, actual exports are extremely small, around $2 \frac{1}{2} \%$ of developing country exports. The potential gains for both developing country exporters and for consumers in developed countries from a significant opening to 
agricultural trade in the OECD are probably larger than for another trade category, suggesting high priority in this area from a global trade negotiations point of view.

There is, however, a divide among the developing countries in this area, since along with (actual or potential) agricultural exporting countries, there are large net food importers some of whom are indicated in Table 4 and most of whom are least developed poor economies. These net food importers were concerned during the Uruguay Round over the potential implications of liberalization in agriculture since they thought that with restraints on agricultural export subsidies agricultural world prices would rise; this would impact on their low income populations, and slow their development.

\section{Table 4}

\section{Agricultural Trade of Developing Countries}

\begin{tabular}{|c|c|c|}
\hline $\begin{array}{l}\text { A. Agricultural Exports of } \\
\text { Developing Countries } \$ \text { billa4 }\end{array}$ & $\begin{array}{l}\text { As } \% \text { of all developing } \\
\text { Country exports }\end{array}$ & $\begin{array}{l}\text { As } \% \text { of all country } \\
\text { agricultural exports }\end{array}$ \\
\hline$\$ 34.9$ bill & $2.5 \%$ & $30.9 \%$ \\
\hline \multicolumn{3}{|l|}{ B. Agricultural Imports \$bill 94} \\
\hline \multicolumn{3}{|l|}{$\$ 32.9$ bill } \\
\hline $\begin{array}{l}\text { C. Some Examples of Net Food } \\
\text { Importing Countries: } \\
(\% \text { of import bill spent on food } \\
\text { items })\end{array}$ & $\begin{array}{l}\text { Egypt (28.4), } \\
\text { Mauritania (29.6) } \\
\text { Equatorial Guinea (36.9) } \\
\text { Congo (26.5) } \\
\text { Algeria (29.5) } \\
\text { Benin }(26.3) \\
\text { Grenada }(28.0) \\
\text { Jordan }(20.8) \\
\text { Samoa }(27.1) \\
\text { Senegal }(28.7) \\
\text { Somalia (32.5) }\end{array}$ & \\
\hline
\end{tabular}

Source: UNCTAD (1997a) Table 4.2. 


\section{Trade in Textiles and Apparel}

A further key important component of developing country trade involves trade in textiles and apparel, discussed in Table 5. While only $12 \%$ of all developing country exports, textiles and apparel typically provide the first labour intensive manufactured product which developing countries produce as they surge in their trade and move ever more heavily into production of low wage industrial products. Thus, countries such as Korea had export performance in their early stages of industrialization in the 1960's with $50 \%$ or more of their exports being in textiles and apparel. Even today, as Table 5 indicates, countries such as Pakistan have over $60 \%$ of their exports in textiles and apparel, and similar high numbers for Bangladesh. Hence, textiles and apparel are an important trade item for a number of developing countries. Some have also noted that they also represented the first stage of successful industrialization that OECD countries such as the UK went through in the 1850's.

Textiles and apparel exports, however, have been restricted as a result of the GATT Multifibre Arrangement(MFA), a system of bilateral quotas between developed and developing countries designed to slow adjustments in importing countries because of the low wage and regionally concentrated use of labour involved. As a result, global liberalization in textiles and apparel has become a central issue for the developing countries, especially since this system of bilateral quotas has made it more difficult for new entrants (or potential new entrants) to textiles and apparel trade to obtain market share. Some have even suggested that the presence of the Multifibre Arrangement has been a major impediment to the integration of Africa into the global economy, because of the knowledge that any significant surge of textiles and apparel by them (included that 
generated by inward foreign investment) would eventually provoke new trade quotas.

Table 5

\section{Developing Country Trade in Textiles and Apparel}

\begin{tabular}{|l|l|l|}
\hline $\begin{array}{l}\text { A. Value of Developing } \\
\text { Country Exports of Textiles } \\
\text { and Apparel \$bill } 94\end{array}$ & $\begin{array}{l}\text { As \% of all developing } \\
\text { country exports }\end{array}$ & $\begin{array}{l}\text { As \% of all developing } \\
\text { country exports of industrial } \\
\text { products }\end{array}$ \\
\hline$\$ 173.5$ & $12.3 \%$ & 40.1 \\
\hline $\begin{array}{l}\text { B. Key countries with trade } \\
\text { dependence on textiles and } \\
\text { apparel. (Share of textiles } \\
\text { and apparel in total exports) }\end{array}$ & $\begin{array}{c}\text { Pakistan, Mauritius, India } \\
(66 \%) \quad(53 \%) \quad(28 \%)\end{array}$ & \\
\hline
\end{tabular}

Source: UNCTAD (1997a) Table A.11.

\section{Outsourcing and Trade}

Outsourcing exports, a further important feature of developing country trade, are highlighted in Table $6 .^{5}$ These data indicate that over $40 \%$ of developing country exports are produced by domestic affiliates of foreign parent companies. Outsourcing, the more extreme form of this activity, refers to the relocation of production from developed to developing countries, to take advantage of low wage labour, improving infrastructure, and increased openness within the developing world. In the case of the United States, over a period of twenty years significant amounts of outsourcing have gone to Mexico, concentrated in the Maquiladora zone twenty miles to the south of the United States. In this zone, components initially produced in the US are

\footnotetext{
${ }^{5}$ The significance of outsourcing for US trade is explored in Feenstra and Hanson (1996).
} 
assembled using designs from parent establishments, before being re-exported to the US. In some cases complete assembly occurs (as in the case of autos).

Outsourcing has been strongly promoted by a number of developing countries through export processing zones, and outsourcing activity is often claimed to account for nearly $80 \%$ of China's manufactured exports. As outsourcing has grown, so has the importance of this trade to the developing countries has become ever more crucial, and both its form and treatment in any future global trade strategy is key to individual countries. However, in this area of trade the commercial interest of large OECD companies in keeping export markets open and barrier free is a key asset to the developing countries. This form of trade is not only growing rapidly, but is virtually barrier free and will likely stay so given the policy influence in OECD countries of parent countries. In such cases, the policy issue for host countries may be more their terms for receiving FDI (tax and regulatory treatment), than the trade treatment of exports.

\section{Table 6}

\section{Outsourcing Exports and Developing Country Trade Performance}

\begin{tabular}{|l|c|}
\hline $\begin{array}{l}\text { Foreign Affiliate exports originating in } \\
\text { developing countries \$bill 94 }\end{array}$ & \$585 bill \\
\hline As \% of total exports & $41.6 \%$ \\
\hline $\begin{array}{l}\text { Key outsourcing countries: } \\
\text { China, Indonesia, Mexico }\end{array}$ & \\
\hline
\end{tabular}

Source: UNCTAD (1997b) Table A.5. 


\section{Services}

Table 7 summarizes the developing country situation in a further key and growing element of global trade, namely trade in services. Services cover banking, insurance, transportation, telecomms, tourism and other trade in non-tangible items. These non-tangible items are thought to account for around $30 \%$ of global trade of both goods and services. Table 7 indicates both that these numbers are smaller for the developing countries, and that the developing countries are net importers of services.

The developing countries often see themselves as having significant export opportunities in key segments of service trade. One example is the success enjoyed by India in exports of software. However, there are still many service areas where significant impediments to trade remain in both the developed and the developing world, through domestic regulation, such as in financial institutions, transportation and other areas. There is also concern in the developing world that full global liberalization in these areas could eliminate domestic capacity for some of these service related items (such as banking). For the lower income countries tourism is the most significant component of this trade. Generally, services are more rapidly growing than other areas of trade and more heavily restricted. Barrier removal began in a small way in the Uruguay Round, but will be a major issue in a new Millennium Round beyond. 
Table 7

\section{Growth of Services Trade and the Developing Countries}

\begin{tabular}{|c|c|c|}
\hline & \$bill 96 & As $\%$ of merchandise trade \\
\hline Service Exports ${ }^{1}$ & $\$ 227$ bill. & $15.2 \%$ \\
\hline Service Imports ${ }^{1}$ & $\$ 282$ bill. & $20.1 \%$ \\
\hline $\begin{array}{l}\text { Tourism as a \% of service } \\
\text { exports }\end{array}$ & $\$ 94$ bill. & $33 \%$ \\
\hline
\end{tabular}

\section{South-South Trade}

Finally, Table 8 reports data on South-South trade; trade between the developing countries. This was at low levels in the 1970 's, but in recent years has been more rapidly growing than developeddeveloping country trade. It now accounts for around $11 \%$ of world trade, but importantly around $40 \%$ of developing country exports. As Table 8 indicates, both these trade shares have increased substantially over the five year period 1990-1995. Least developed countries now source over one half of their imports from other developing countries.

Over the years it has often been suggested that increased South-South trade could ultimately represent a major opportunity for the developing countries in the trading system, but because of 
its seeming small size, this source has been frequently discounted. The issue is, therefore, at what point does South-South trade represent a large enough trading opportunity for the developing countries to become a motor for growth, and how important could it be over the next two decades. Given the current share of developing country exports that go to other developing countries, and the significantly higher growth rate of South-South trade compared to world trade in recent years, the indication is that this is an important source of opportunity for developing countries in their trade.

Table 8

South-South Trade

\begin{tabular}{|l|c|c|}
\hline $\begin{array}{l}\text { South-South Trade in 1994 } \\
\text { (US \$bill) }\end{array}$ & 539.8 & \\
\hline As a \% of World Trade & $7.7(1990)$ & $11.1(1995)$ \\
\hline $\begin{array}{l}\text { As a \% of Developing } \\
\text { Country Exports }\end{array}$ & $33.5(1990)$ & $39.6(1995)$ \\
\hline
\end{tabular}

Source: UNCTAD (1997b). 


\section{The Policy Framework For Globally Based Economic Development}

\section{A Future WTO Millennium Round?}

A central global trade policy issue for individual developing countries is their stance towards a future trade negotiating Round under the WTO. This is now widely believed to be likely to be initiated in the year 2000 to coincide with the Millennium (hence the title the Millennium Round), although there are still major issues to be resolved before such a Round can be launched. A central unresolved issue concerns negotiating authority in the United States, and the lack of appetite for new trade negotiations within the Congress. But despite this in many parts of the world, and particularly so in Europe, there is now a substantial gearing up underway for a new Round. $^{6}$

Since the creation of the GATT in 1947 (subsumed into the WTO in 1994) there have been eight negotiating rounds, ${ }^{7}$ even though there is no inevitability which leads from one Round to the next. These Rounds through negotiated exchanges and concessions reducing tariff barriers on manufactured products are widely thought to have lowered tariff barriers between OECD countries to the point that they are now relatively insignificant barriers to trade, with other trade barriers now more important; including for developing country exporters, textiles and apparel

${ }^{6}$ See the discussion of the possible content of a new Trade Round in the recent Institute of International Economics volume edited by Jeffrey Schott (1998).

${ }^{7}$ The most recent, the Uruguay Round, concluded in 1994; although WTO Director General Renato Ruggiero has suggested (see his speech in Schott (1998)) that WTO negotiations since, in information technology, financial services, and telecoms are of sufficient importance that they should be grouped together and be considered as a ninth Round, even though such a round was not formally declared. 
restrictions as well as anti-dumping duties and actions, and restrictions in agriculture.

Understanding what a Millennium Round might imply involves prior understanding of the trade policy problem it is designed to solve. One feature of the Uruguay Round decisions was that they specified substantial detail as to their implementation over a long period of time (as much as 20 years). The Uruguay Round mandated a mini negotiation in agriculture within five years of the conclusion of the Round, and granted special delays to developing countries (and especially the least developed) for implementation in such areas as intellectual property and agriculture. The Round also saw agreement by developed countries to terminate trade restrictions against textiles and apparel under the Multi-Fibre Arrangement by 2004, although the initial phase in of these arrangements has caused disquiet among developing countries as to what may replace the MFA. Thus some have suggested that the core of a new Millennium Round could be to concentrate on implementation issues stemming from the Uruguay Round. As such this would be a distinct departure from previous WTO Rounds which have had a strong focus initially on tariff reduction and then on other barrier reduction. Moreover, the decisions from the Round also created a new permanent forum of bi-annual ministerial meetings which some argued at the time could serve to replace Rounds through ongoing permanent negotiation, and so the rationale for a separate and new Round is even questioned in come circles.

Others have suggested that a Millennium Round could instead be dominated by discussion of socalled new-new issues ( issues which go beyond the new issues discussed in the Uruguay Round; services, investment, intellectual property). These include trade and the environment, competition 
policy (with its trade implications), trade and investment, and trade and labour standards. Developing countries have been concerned about these developments in global policy discussion because they see them as issues on which developing countries will likely be pressured to undertake measures which could slow their growth and development (such as in environment and labour standards) under a threat of increased trade barriers if they do not comply. Their fear is that a new Millennium Round rather than focussing on further reductions in trade barriers, as in the past, may become embroiled in discussion of conditional increases in trade barriers which could close export markets.

A third view of the Millennium Round focusses on it as an opportunity, created in large part by the Uruguay Round, for large new market opening globally through yet more bargaining of reciprocal exchanges and concessions in similar vein to previous Rounds. The argument is that following the Uruguay Round, in a number of areas there are now negotiable trade instruments which were not there before. In agriculture, for instance, tariffication of existing agricultural trade restrictions, including the recent tariffication of rice restrictions in Japan (at levels of over $1000 \%$ ), has created transparent negotiable tariff instruments which can now be the subject of an exchange of concessions. The elimination of quota restrictions under the Multifibre Arrangement in 2004 will leave in place tariff barriers in the OECD countries which are the highest on manufactured products, and once again represent a negotiable instrument for reciprocal exchange.

Developing countries greatly expanded the coverage of their tariff bindings in the Uruguay Round to cover nearly $80 \%$ of their imports (as against a little over $20 \%$ previously). Reciprocal 
exchange possibilities also arise here. There are also arguments that many more restrictions in services could also become negotiable in a wide ranging reciprocal exchange in such a framework, and in both developed and developing countries.

This third view of the architecture of a Millennium Round is thus as an opportunity for a major expansion of the reciprocal exchanges and concessions beyond manufactures that have characterized previous tariff cutting negotiations in the WTO (GATT) into agriculture and services, and also into key residual manufacturing items such as textiles. In this case the opportunities for the developing countries to generate fresh market opening become significant because of the chance to reduce key trade barriers which they face, particularly in textiles and apparel, but also in agriculture and some service items.

A future Millennium Round, if it comes to pass, may well contain all of these elements, and as such present both opportunities and threats to the developing countries. ${ }^{8}$ The threats are that they could be subject to increases in trade barriers unless they move towards compliance with various forms of OECD driven domestic policy changes such as in environment and labour standards. On the other hand, major opportunities may be present for market opening reciprocal exchange in which the developing countries, continually increasing in relative size compared to the developed countries, have significant leverage.

\section{Regionalism}

Another key element which will affect the future position of the developing countries in the global

\footnotetext{
${ }^{8}$ See the discussion of these alternative architectures for a new Round in Whalley (1998).
} 
trading system is regional trade agreements. ${ }^{9}$ Regional agreements have been an ever present feature of the post war trading system, but in the last ten years they have grown substantially in profile. The first round of post-war regional trade agreements came into the system in the 1960's, particularly with the creation of the European community (later the EU), and also with regional trade agreements in many parts of the developing world. These agreements, and especially the 1957 Treaty of Rome, created the precedent for coexistence of regional agreements with the GATT, even though regional agreements were a clear violation of the spirit of non-discrimination central to the GATT. Indeed, in the 1960's the Kennedy Round of GATT trade negotiations were in large part a result of the creation of the EU, and the perceived need of the United States to deal with their access problems to European markets through trade bargaining in the GATT system.

In the late 1980's, however, frustration over seeming slow progress in multilateral negotiation and the exploitation of tactical linkage between multilateral and regional negotiation by some countries produced a racheting up in regional trading agreements, and especially so with the 1987 Canada-US Agreement. Subsequently, trilateralized to include Mexico in NAFTA, the creation of a regional entity in North America set off a series of further concerns. Smaller countries strongly wanted to be part of one trade agreement or the other, and these regional entities in turn began to pursue new options to expand their network of trade agreements before their rival did so. This was particularly the case with the EU, who in recent years had been either negotiating or discussing regional trade agreements with South Africa, India, and others, as well as association

\footnotetext{
${ }^{9}$ Winters in Schott (1998) provides an alternative discussion of this issue and does not come to strong conclusions on the challenges posed by regionalism in the multilateral system for developing countries, although he does see threats.
} 
or accession agreements with Eastern European countries and former Soviet Republics.

These developments have generated a series of further responses; some developing countries have responded by forming their own regional entities, as a precursor to eventual negotiation with larger OECD groups; this, for instance, has been true of MERCOSUR (Argentina, Brazil, Paraguay, Uruguay). Others have hung back trying to avoid entanglements with developing country regional trade agreements so as to make their potential accession to developed world regional trade agreements cleaner. This was the Chilean approach, but the Chileans in turn found that concerns in the US Congress have made it difficult for them to pursue this negotiation route, and as a result have subsequently joined MERCOSUR. In Asia, there has been new regional activity in the ASEAN, which has moved towards a regional trade agreement (AFTA, the ASEAN Free Trade Area) in contrast to the framework for regional cooperation and the defence alliance which it was at its creation. Even in Africa there have been new attempts to revive regional trade agreements, based on the argument that regional trade grows more rapidly than global trade.

Some of these new regional arrangements have also taken the form of smaller countries approaching larger countries seeking safe-haven trade arrangements. In these, the smaller country often pays what is akin to an insurance premium in the form of domestic policy restraints of various kinds beneficial to the large country, in return for firmer guarantees of access to the larger market. This characterization of the Canada-US Trade Agreement, for instance, has recently been offered by Perroni and Whalley (1998). From the point of view of smaller developing countries 
the concern is that they will increasingly need to pay such premia in order to join regional trade agreements and that later entrants will be called on to pay larger premiums; a redistributive element in these arrangements adverse to smaller countries. As a result, a continued spread of regional arrangements is generally seen in the developing world as hostile to the interests of the developing countries.

Out into the next decade, the continued speed of regionalism therefore presents dilemmas for the developing countries. On the one hand, there is a fear that with the OECD countries moving towards more clearly defined regional blocs, that unless individual developing countries become part of one of these blocs they will eventually suffer, particularly if there is eventually trade retaliation between these regional entities. On the other hand, these entities may finish up retaliating against each other in ways, which could yield preferential access for developing countries to their markets, and if they any way generate growth and trade developing countries will share in this to some degree

\section{Access Problems}

A further set of issues for the developing countries are future access problems that they are likely to encounter in OECD markets, independently of a WTO negotiating Round or developments on the regional front. As mentioned above, tariffs in OECD countries on manufactured products, to all intents and purposes, have been eliminated as a result of exchanges of concessions in the Uruguay Round, with the notable exceptions of textiles and apparel and agriculture. Access 
problems that remain for developing countries tend to be product and instrument specific, but these will still pose problems for the developing countries in the decades ahead.

In the instrument area, developing countries have increasingly found themselves to be subject to anti-dumping duties. ${ }^{10}$ Anti-dumping actions are initiated where countries are deemed to be dumping or selling below cost. They are a widely used protective device in the OECD countries, but one which more recently has spread to the developing countries as part of the safeguards offered to domestic producers when trade liberalization occurs. As part of the political consensus underpinning trade liberalization in the OECD countries, if imports surge into domestic markets there are various mechanisms which allow for controls over the flow of imports; anti-dumping is one of the more important of these.

OECD anti-dumping practices over the last twenty years have slowly tightened in the ways they are applied, particularly against smaller countries. There are rules such as cumulation, which allow for the exports of one country to be added to those of another in determining injury; one of the key criteria for the imposition of an anti-dumping duty. There are also rules which allow for the construction of a cost basis for the dumping margin to be determined in the absence of data supplied by individual countries, and repeatedly anti-dumping cases, successful in the initial petitioning process, have resulted in high duties through the use of constructed cost.

\footnotetext{
${ }^{10}$ See the discussion in Spinager (1998b).
} 
In the product specific areas, there are also potential access difficulties to be faced. As noted above, textiles and apparel is the most prominent of these, since while there is a commitment to phase out MFA trade restrictions by the year 2004, it is also widely agreed that the three part phase out procedure which was instituted in the Uruguay Round has to all intents and purposes been tokenesque thus far. ${ }^{11}$ The commitment in the year 2004 to eliminate all MFA restrictions on textiles and apparel in OECD countries has been compared by some developing country trade negotiators as akin to walking off a cliff, which they assume is not going to happen. In another area, agriculture, while the decisions in the Uruguay Round have included agriculture for the first time since the signing of the GATT they have not substantially liberalized trade. Developing countries remain subject to high tariffs on key agricultural exports (including rice and sugar), and the issue for them is how to negotiate these tariffs down so as to improve access.

\section{Non-trade Trade Issues}

A further set of key trade issues for the developing countries out into the early decades of the next century will be the so-called non-trade trade issues. These issues are likely to be part of a future WTO negotiation (including a Millennium Round) and for which a non-trade objective such as improving environmental quality or raising so-called labour standards is tied to possible use of trade sanctions. The broad structure of the proposals made thus far for these areas follows the agreement on intellectual property which emanated from the Uruguay Round. In the intellectual property area, there was a negotiation on a common international standard, such that if countries

\footnotetext{
${ }^{11}$ The experience thus far is discussed in Trela (in Thomas and Whalley (1998)), and also Spinager (1998a).
} 
fail to meet the standard they are subject to dispute settlement and ultimately to trade sanctions.

The trade and environment area has been one which has been particularly contentious, and especially so in the early 1990 's. ${ }^{12}$ In this area, the activities of environmental NGO's trying to establish the principle that the use of trade restricting measures to improve environmental compliance in exporting countries is legitimate under the GATT have lead to a series of precedent setting trade conflicts. The 1990 dispute over exported tuna catches by Mexico to the US and incidental dolphin kills was especially high profile. Environmental groups in the United States were successful in using the courts to implement trade restrictions, appealing to the US Marine Mammal Protection Act of 1988. These trade restrictions were, however, subsequently found to be GATT incompatible in a preliminary ruling by a dispute settlement panel. This never went beyond its preliminary stages, but its report crystallized the issues and focussed the subsequent debate. To OECD environmental groups, the GATT was widely seen as environmentally unfriendly and even incapable of allowing trade restraints in the name of what was viewed as sensible environmental policy. But from the developing country point of view, trade restraints of this form were seen as potentially harmful to their growth and environmental prospects, and inconsistent with the general principles embodied in the GATT of helping developing countries speed their growth and development through growing trade.

Conflicts over trade measures for environmental management continued through the 1990's. Thus

\footnotetext{
${ }^{12}$ The recent evolution of the trade and environment debate is discussed in Uimonen In Schott (1998), as well as in Uimonen and Whalley (1997).
} 
far, the developing countries have remained cautious of any proposals to negotiate a trade and environment agreement, and in the 1996 Singapore WTO Ministerial Meeting were successful in keeping further negotiation off the agenda. But the issue remains, and will likely surface again in the Millennium Round agenda setting process.

Another related issue is labour standards. ${ }^{13}$ Labour standards involve restraints on various production practices which use labour in ways which are seen in the OECD countries as infringing either labour or human rights. These particularly involve the use of child labour, especially young children working for long periods of time, with allegations made of adverse labour practices in carpet factories in such countries as Pakistan, and also cover the use of prison labour, and in some versions of labour standards advocacy, non union labour.

The proposal strongly advanced by the United States is to agree on a series of core standards, not dissimilar to those already in ILO, with violations of labour standards being subject to dispute settlement, and eventually, to retaliation. As with trade and environment, the developing countries have been steadfast in resisting attempts to engage them in negotiation on these matters, on the grounds, again, of the potential impairment of their growth and developmental prospects, but as with trade and environment the issues remain.

There are also concerns that this approach of using trade sanctions as a form of policemen over

${ }^{13}$ See Elliott's paper in Schott (1998). 
domestic policies could spread beyond environment and labour standards. The developing country fear is that other issues could enter into this category, such as trade and human rights, and trade and political rights. Concerns over trade and environment and labour standards, therefore, also embody worries over the precedents involved. The effect of these developments could ultimately be to raise trade barriers against developing countries, especially if fears of domestic protectionist interests exploiting these opportunities for protective rather than genuinely held environmental or other concerns were to be realized. The contrast relative to the earlier post-war years where trade barriers generally came down is especially marked; the concern is now that there may be circumstances under which trade barriers against developing countries go up.

\section{New-new Issues}

Beyond the non-trade trade issues discussed above, there are also a series of further issues which are only now becoming central to the trade policy agenda but also form part of a new potential trade Round.

One is the issue of electronic commerce, so-called E-commerce. In electronic commerce, the issues reflect the rapid growth of the internet as a vehicle for the conduct of trade. The value of trade conducted on the internet seems likely to explode in the next few years, but most of it poses no immediate issues for trade policy since if goods are ordered on the internet but are physically shipped, they are dealt with at the border like any other shipped commodity. 
The immediate focal point of the e-commerce debate has been more on the impact of transactions which are executed on the internet. This type of E-commerce includes financial services, and delivery of various kinds of professional and other services (including entertainment materials) which are wholly delivered over the internet. There are proposals from the United States that all such transactions should remain free of all tariffs (indeed how to collect tariffs in such cases is unclear), and further discussion has been devoted to the tax treatment of these items.

More generally with E-commerce there are debates as to how it affects the position of the developing countries. A recent WTO (1998) report has suggested that developing countries would benefit substantially from a general spread of E-commerce, because the internet represents a significant reduction in the transactions costs of conducting trade and as the developing countries face higher costs than other countries at present, they would benefit more than proportionally from this new format for the conduct of trade. If this is correct, E-commerce may offer new opportunities to the developing countries for their trade growth.

In the competition policy area, the issues are even more complex and it is less clear what the interests of the developing countries are. On the one hand, there is talk of partial harmonization of competition policy, but at the same time many developing countries have no competition policy statutes. Some countries are fearful of the costs and complexity of instituting such regimes, remembering the obligations they incurred to install intellectual property regimes in the Uruguay Round. On the other hand, there are opportunities within a potential competition policy 
negotiation that developing countries may wish to explore. One involves questions of price fixing and collusive behaviour by supplying firms from large countries into small markets, where the national government in the smaller market has no extra territorial reach. Here the issue is the potential use of tariffs as a vehicle for offsetting the collusive practices involved. Another is whether the institution of competition policies in the developing countries could lead to significant gains because of the concentrated nature of their domestic markets, and a general opening up of their markets through changes in competition policy.

\section{Developing Country Interests in a New Post Bretton Woods Architecture}

Besides the issues that fall under the general orbit of the WTO and the new Millennium Round, there are also a set of issues concerning developing country participation in the trading system which are part of the emerging debate on a new post Bretton Woods architecture. The Bretton Woods system, as is well known, emerged from the 1940's with the tri-partite structure of the World Bank, the GATT (now the WTO), and the IMF.

This structure is increasingly viewed as being ineffective, given the operation of the contemporary global economy and the problems which it faces. This has been made evident to many by the events surrounding the recent financial turbulence. As an example, this financial turbulence took place within a regime of domestic banking regulation but no international regulation of banks, and many of the practices of OECD banks in developing countries (such as in Indonesia) would probably not have been acceptable to an overarching international regulatory body. There is also 
no set of global competition statutes which operate antitrust policies on a global basis rather than a country basis, and neither will one result from a WTO negotiation on competition policy. In area after area, it is clear that the arrangements which we have inherited from the 1940's are designed to deal with the problems of the 1940's rather than the problems of the 1990's. The Bretton Woods system, for instance, only treats interactions between countries as being based on trade and finance; there is no recognition of physical interaction and recent calls for the formation of the World Environmental Organization reflect these concerns.

On a broader plane then, beyond the WTO, there are and will continue to be ongoing discussions about new global arrangements, with a reconfiguration of and restructuring in global institutional forms, involving particularly the World Bank, the IMF and the WTO. The developing country interest in these needs to be clearly articulated. On the one hand, developing countries have come to rely on the World Bank and the IMF as much needed shorter (or longer term) sources of cheaper developmental finance. On the other hand, these bodies are seen in some circles in these countries as being driven by an OECD inspired policy agenda which doe not mesh with local concerns. Strengthened agencies with even more powers will be viewed with caution and even alarm in some countries; while more financing and strengthened rule regimes to deal with country problems (as in the competition area) could prove beneficial.

\section{Non-Trading System Trade Issues}

Another set of issues beyond the WTO, and of great potential relevance to the developing 
countries, reflect ways in which non-trading system issues have implications for the evolution of developing country trade. The trade implications of carbon emissions reductions arrangements are a central element in this category.

These have been discussed recently as part of the debate on the Kyoto Protocol negotiated 18 months ago. Any attempt to reduce carbon emissions to meet the Kyoto target of a $7 \%$ reduction in 1990 emissions by 2012 will have associated with it a substantial increase in energy prices. Some modelling calculations suggest that induced increases in energy prices could have large impacts on world trade; trade in manufactured products which are energy intensive could fall sharply, perhaps by 20 to $50 \% .^{14}$ In addition, the revenue implications of emissions reductions mechanisms could themselves also be substantial. Non WTO issues which affect the trade of the developing countries may thus prove important for the developing countries in deciding whether they focus on exports of manufactured products or are remain in commodity based exports. An environment of shrinking global trade in manufactures obviously has substantial implications for outward oriented developmental strategies.

\section{Negotiability}

Within this discussion of a global policy framework, it is also important for negotiating strategies to emerge which build on the leverage of developing countries; recognizing how much they actually have and how they can best use it. It has generally been believed that developing

\footnotetext{
${ }^{14}$ See Piggott, Whalley, and Wigle (1993).
} 
countries are small in trade terms, and therefore have limited amounts of leverage they can use in global trade negotiation. This, of course, is not true in terms of international trade volumes, since developing countries account for over $30 \%$ of global trade, but developing countries are a fractured group of countries (more than 100), even though within that group there are certain countries which are large and significant. Brazil for instance, is the tenth largest economy in the world.

In the past the developing countries have pursued a negotiating strategy under which they have claimed to have problems which are similar across all developing countries but unique to developing country status. This approach, identified by the phrase "special and differential treatment" (S \& D), defined their global negotiating strategy in the 1960's and the 1970's. The argument is that they have common problems and they should negotiate globally as a group to achieve improvements in their position, and jointly seek ways to first implement and then improve their special and differential treatment. This was manifest in the generalized system of preferences which resulted in the 1970's and which granted them special lower tariffs for their exports to OECD.

In the 1980's, however, it became widely believed that developing countries had not in fact received much in the way of substantive benefits from special and differential treatment, and in turn their individual country interests were such that they criss-crossed one another and pursuit of country interest made more sense than pursuit of common interests. In the Uruguay Round, 
therefore, we saw developing countries on different sides of the same issue. Countries such as Argentina were strongly arguing for liberalization in agriculture, while agriculture net importing countries, such as Jamaica and Egypt, were arguing strongly against such liberalization. We also had examples of coalitions being formed between developed and developing countries; in agriculture the example was of the Cairns Group, a coalition involving both Argentina and Australia and others, trying to pressure the European community for more liberalization in agriculture.

The issue, then, of global negotiability for the developing countries in the Millennium Round and beyond is how far they should act jointly to form negotiating coalitions, and how far they should pursue individual country interest. In practice they did both in the Uruguay Round, and will likely continue to do both, and so issues such as labour standards and trade and environment will tend to move the developing countries to a common position, while other issues such as agriculture will again fragment the developing countries.

In the longer term, their more rapid growth also means that they will have ever more leverage and hence their ability to negotiate will become stronger. Crucial to this is the position of China. China's trade has been growing rapidly, and now accounts for more than $60 \%$ of developing country exports of textiles and apparel. China's leverage in trade negotiations is potentially large, and the issue of Chinese accession to the WTO is therefore one which is central to other developing countries. Some developing countries see Chinese WTO accession as positive for them in allowing into the WTO an ally who will be part of a wider coalition and add to its clout. 
Others see benefits in continued Chinese exclusion from the WTO since trade restraints against China on textiles and apparel could continue beyond 2004 (MFA elimination) and be beneficial for them.

\section{Implementation and Policy Making Capacity}

A final issue for the developing countries in assessing the impact of the emerging global framework for the conduct of policy is how to develop the capacity they need to negotiate, and even how to implement the trade decisions which were agreed to in the Uruguay Round. In the implementation area one of the central concerns is intellectual property, where there is a ten year lag for the least developed countries following implementation in ten years. Issues of trade sanctions in this area will thus not impinge on these countries for a twenty year period following the adoption of the decisions in 1994. But, in many countries new intellectual property regimes will need to be instituted which are costly, and require a capability and capacity which goes beyond that which developing countries have.

In turn, many developing countries also have problems with their negotiating capacity. In the Uruguay Round negotiations several countries participated only to a limited extent, partly fuelled by their belief that they had no negotiating leverage, and partly by the costs of maintaining delegations in Geneva. With upcoming WTO negotiations in store, the question is how to enhance their negotiating capability, what forms of pooling can take place across countries to maintain common representations in a more cost effective manner, how to identify the most 
important issues for them to negotiate on, and how these negotiations are to be concluded.

\section{The Future For The Developing Countries In The Trading System}

Given the discussion of country trade performance and where the trading system finds itself as we approach the new Millennium Round, what could the future hold for the developing countries? How will global trade volumes and product composition evolve over the next decade, and with what implications for the developing countries? As Hamilton and Whalley (1996) discuss, the decades since the 1940's have been remarkable for ever increasing interdependence within the global economy. Since the mid 1940 's, global income growth has been perhaps 2 to $2 \frac{1}{2} \%$ per year in real terms, with higher growth rates in the 1960's and 1970's, some slippage in the 1980's and a further acceleration in the 1990's. In contrast, trade growth has occurred at approximately double these rates; somewhere in the region of 5 to $6 \%$ over the 40 year period. In the mid 1990 's, trade growth was approximately three times the rate of growth of income at around 10 to $11 \%$ per year. It is this dramatic trade growth which as much as anything else has facilitated the rapid integration of the manufactured product exporting developing countries in Asia and Latin America into the global economy.

The future for the developing countries in the trading system will be to a large degree determined by whether or not these trade growth figures continue. It should be remembered that long swings in trade performance in the global economy have been very uneven. From 1870 to 1913 there were large increases in international trade as a fraction of national income, but between 1913 and 
the outbreak of the second world war, there were declines, accelerated by the depression of the 1930 's but also brought about by increases in trade barriers over the whole of the 1920's and inconvertible currencies in the 1930's. In the depression of the 1930's, Kindleberger's (1973) estimate is that world trade fell by between 75 and $80 \%$ over a two year period.

The strongly held belief in the likely continued success of outward oriented trade strategies is based on the premise that there will be a continuation of the strong global trade performance of the last 50 years. It presumes no significant barrier increases; no unwinding of the direct foreign investment that has fuelled trade growth; in short a continuation and even acceleration of present trends of globalization. ${ }^{15}$ The rate of growth of foreign direct investment has been even more rapid than for trade. Throughout the 1980's, and only with a drop in the recession of the early 1990 's, foreign direct investment globally has been growing at approximately $25 \%$ per year until the onset of current financial crises. This builds from a small base in the1970's, but these growth rates are in excess even of those for trade, and reflect ever more interdependence in the global economy and a progressive reduction in barriers to investment as well as to trade. And as this has happened, interaffiliate trade as a fraction of total trade has grown, to the point that FDI in recent years has itself become a major engine of growth for trade.

\section{Factors Underlying Trade Growth}

${ }^{15}$ Although Tussie's (1998) recent analysis of the situation in Argentina argues that a more cautious approach to trade is now evolving there; focussed on regional rather than global trade growth and reinstating some of the protection for the domestic market, in part through antidumping measures. 
There are clearly a variety of reasons as to why trade has grown so rapidly over this period, even if there is disagreement in the literature as to which is the most important. Some point to sharp reductions in transportation costs, with changes in the type of trade. Older trade in bulky items has been replaced by trade in light items such as computer chips, with even intangible trade now taking place over the internet. Barriers to trade posed by transportation systems, which were substantial, are now much lower because the form of trade has changed.

Another factor is technical change, and particularly the growth of communications devices; first phones, then faxes, the internet, and global media. There is now awareness in all countries of global products. It has become profitable to produce and market for the global marketplace, and to develop products which establish global brand identity and are traded on a global basis. Again global trade growth inevitably accompanies these technological developments.

Finally, there is the global policy framework. The policy direction within the global economy since the 1940's has been one of progressive reductions in trade barriers, driven in part by a global determination not to repeat the 1930's and to keep markets as open as possible. This occurred first under the General Agreement on Tariffs and Trade (GATT), and since 1994 in the World Trade Organization (WTO), with global trade rules applied and trade negotiations completed. The Uruguay Round, ${ }^{16}$ concluded in 1994, was the most recent of these and covered a wide range of issues, from agriculture to intellectual property, and textiles to dispute settlement. This process

\footnotetext{
${ }^{16}$ Yeats (1994) and the papers in Martin and Winters (1995) provide quantitative assessments of the impacts of the Uruguay Round on developing countries.
} 
has established a general presumption of an ever more open global economy with declining trade barriers. Developing countries, while not significantly affecting the outcomes of these negotiations, have nonetheless been able to base policy strategies on the hypothesis that they would tend to face an ever more open global economy with lower barriers.

\section{A Fallacy of Composition?}

The system has, however, moved from one in which a small number of countries were focussed on an outward oriented trade driven strategy to growth and development in the 1960's, to a situation where today the vast majority of countries are pursuing such strategies while the growth rate of the OECD markets absorbing these imports remains largely the same. The issue is whether there is a fallacy of composition involved; can developing countries continue to generate trade growth of the type that would be sufficient meet the development objectives of all of these countries if OECD growth rates do not accelerate. As more countries follow these strategies, the initial experience can be high export growth rates from an initial low trade low wage base; but whether sustained trade growth can occur for all or most of these countries over a period of decades sufficient to replicate the experiences of Korea and Taiwan is the issue. In turn, foreign direct investment flowing into these countries, while linked to strong trade performance, remains heavily concentrated, raising further questions also about the sustainability of the process for the majority of countries.

And low income (and typically smaller) countries, in Africa and elsewhere, who have generally 
not participated in this growth process pose problems. Some have suggested that these countries now have low wage rates, and even with poor infrastructure offer large opportunities for inward foreign investors moving to exploit these opportunities. This may be the case in such areas as textiles and apparel, since with the impending elimination of the Multifibre Arrangement and country specific quotas (which will follow in 2004) ${ }^{17}$ a major blockage to trade growth for these countries may be removed. But for now, few of the low income countries that have been encouraged by donor agencies and others to think in terms of an outward oriented trade strategy have yet to see fruits for their endeavors.

\section{The Direction of Barrier Change}

A further key element in a strategy for participation in the global trading system is whether there will be changes in the global policy framework of a type not seen before. As noted above, the scenarios for such change occurring focus on a number of elements.

One concerns the level and type of trade barriers that the developing countries are likely to face in the next two decades. For the last fifty years, developing countries have proceeded with their trade strategy under the general expectation that trade barriers around the world would continue to come down. This reflected the process of ongoing negotiation both in the GATT and the WTO. The developing countries have been key to this process both through ever improved

\footnotetext{
${ }^{17}$ See Spinager's (1998a) recent discussion of the situation on the phase out of the MFA.
} 
access to developed country markets, and also through large unilateral reductions in their own trade barriers made later on in the process (late 80's/early 90's). They were, however, able to liberalize unilaterally reasonably secure in the belief that export markets for them were open, and barriers against them were, if anything, going to fall further.

The question is whether after all these reductions there is still scope for even further reductions in barriers that will significantly affect trade on the upside. The scope is there in key sectoral areas, such as services, agriculture, and textiles, but for the developing countries to rely on further generalized barrier reductions fuelling their trade growth for the next 20 years seems myopic. ${ }^{18}$

At a technical level, efforts by domestic interests within OECD countries, and also now increasingly in developing countries, to offset the effects of tariff reductions by other protective barriers such as anti-dumping seem to be a factor. For now, the trade coverage of these measures is relatively small, but the levels at which barriers which have been implemented is large, and concerns have been expressed by many that the elimination of the Multifibre Arrangement could ultimately lead to an increase in anti-dumping measures applied against textiles and apparel.

A broader concern is that trade barriers will increasingly be linked to non-trade objectives through the use of trade threats. This direction for policy has already entered the trading system through the agreements on intellectual property in the Uruguay Round, but there have been more wide

${ }^{18}$ And new regional agreements seem unlikely to give much added benefit on the access side to OECD markets (since barriers are low), and may serve to fragment global markets. 
ranging proposals made by the developed countries to link the use of trade sanctions to compliance with environmental policy objectives in the developing world, ${ }^{19}$ and also to use trade sanctions to uphold labour standards. In all these cases, standards are to be set for the non-trade objective, and these are to be enforced through the use of WTO approved trade sanctions if noncompliance takes place. Hence, having participated in a trading system in which trade barriers were generally coming down for the last fifty years, and are now so low that further declines are unlikely, these developments suggest a risk of trade barriers going back up. Export markets will not close, but exports may grow at a slower rate, and they may experience selective closing.

\section{Broadening Negotiations}

A further element in this changing policy framework is a trend towards broadening of negotiations beyond trade, so as to inject other non-trade matters into trading system debates. There are pressures for broadening beyond the Uruguay Round into the New Millennium Round, to include environment, competition policy, investment and other matters.

Generally speaking, the developing countries have been resistant to attempts to broaden the agenda of trade related negotiations, on the grounds that most of these are disadvantageous to them. Their concern has been to push for a negotiating framework which will limit the damage. This containment approach has been relatively successful in certain areas, such as in slowing the pace on environmental-trade negotiations and on labour standard negotiations in the 1996 Singapore WTO Ministerial Meeting, but they were unsuccessful with intellectual property in the

\footnotetext{
${ }^{19}$ See Whalley (1996) and Uimonen and Whalley (1997), both of which discuss the WTO and trade and environmental linkage.
} 
Uruguay Round. This was, in part, because many developing countries had complied bilaterally with developed country pressures on the intellectual property front exerted in parallel regional negotiations to the Uruguay Round.

In this broadening process, however, there will also be opportunities to pursue new directions which could be advantageous, and even to do so aggressively. By way of example, there is no logical reason why future negotiations should be limited only to intellectual property rights; they could also be expanded to include other forms of property rights. In the Kyoto process, for instance, the developing countries have thus far taken a passive approach of arguing that carbon emission problems are fundamentally problems of the developed world. They have withdrawn from the negotiations in the hope that they would have neither disciplines nor obligations imposed on them, and, so far, have largely achieved this outcome. However, an activist developing country approach to a property rights negotiation could use the argument that all countries have only limited rights to emit carbon into the upper atmosphere, and that the developed countries have already overused their rights to do so through past emissions. The argument is that they should compensate the developing countries if they now continue to emit carbon. An aggressive pursuit of property rights in this and other areas could yield the developing countries both potential economic benefits and negotiating leverage.

Trade and environment is, again, an area where developing countries have largely taken an approach of withdrawing from negotiations and arguing that linked negotiations should not take 
place. Developing countries have tried to avoid WTO legitimized environmental trade sanctions being used against them, because they are seen as a mechanism through which pressure could be placed on them to undertake various kinds of domestic environmental policy initiatives which they see as potentially growth retarding. However, developing countries are custodians of key global environmental assets, such as forests, and with existence value placed over these assets by the environmental groups in the OECD countries, there is negotiating leverage for the developing countries in linked trade and environment negotiations. Environmental concessions might be one way in which developing countries could get improvements in trade access in key areas of interest, and so increase their economic performance. The point, put simply, is that broadened negotiations represent both a source of both opportunity and risk for the developing countries, but the approach taken by them thus far has been to emphasize the risks and the downside, without aggressively exploring positive upside opportunities. This could be an area to reconsider.

\section{Post Bretton Woods Institutions}

There is also a clear shift which has taken place following the recent crises in attitudes towards the role and operation of international institutions globally. Things are in flux both intellectually and politically, and here the developing countries have a major opportunity to help shape the post

crisis global institutional framework out into the early decades of the next century. ${ }^{20}$ Our present day global institutions, for want of a better description, are caught in a time warp of the 1940's.

\footnotetext{
${ }^{20} \mathrm{~A}$ recent piece by Richard Blackhurst (1998), a former director of research at the WTO, provides a useful summary of views on the role of the WTO in the global economy. See also Anne Kreuger's (1998) thoughts on the future of the IMF and the World Bank.
} 
The IMF, the World Bank and the GATT (now the WTO) were institutions designed in the 1940's to deal with particular problems of the 1940 's, connected to the events of the 1930 's ${ }^{21}$ and then the subsequent military conflict. They are not institutional arrangements designed to deal with the problems of today's globalized economy in which there are no clear global entities to redefine the authority leaking away from national governments. Our present global entities have only weakly defined powers. For instance, in the global area, we have no global regulation of financial institutions comparable to that which exists within nation states. There is no global antitrust policy comparable to that which operates within nation states. The institutions of the 1940's were designed on the premise that the only interactions between nation states were in trade and finance, with no physical interaction as in the environmental area, clearly a major omission in terms of global institutional design as seen from today. On top of this, pressures both for new regional arrangements and fragmentation of global arrangements seem to be growing, as in the late 1980's and 1990 's. ${ }^{22}$

Given what has happened in recent financial crises, the next few years could witness a reevaluation of our global institutions and developing countries should be forthright in stating their needs in such institutions. A global competition policy agency, for instance, could be of major advantage to the developing countries. A global environmental agency which facilitates some of the linked negotiations mentioned above could also be of great use. A new global financial authority, moving towards a global central bank, could even be mooted. All of these

\footnotetext{
${ }^{21}$ The parallels to the present day situation are assessed in Perroni and Whalley (1996).

${ }^{22}$ There has been an active debate on regionalism in the trading system, and its implications both good and bad. See Bergsten (1997), Perroni and Whalley (1998), and Frankel (1998).
} 
developments may well provide opportunities for the developing countries to aggressively explore.

\section{Concluding Remarks}

This paper flags concerns over both the performance of the global economy and the institution arrangements underpinning it which may affect the developing countries in a major way for the next few decades. If trade growth over the next two decades does not continue at the levels we have seen in the last two decades (which could happen), developing countries may be forced to shift some of the focus of their developmental strategy away from global aspirations, and more towards improved performance of their own domestic economies. The potential fallacy of composition of a hundred or more developing countries all pursuing outward oriented trade lead growth, compared to the small number of countries that successfully did that in the 1950 's and 1960's seems striking, and especially so in the current global environment.

In addition, clear challenges remain for an overall strategy which does not deal with the uneven performance and participation of countries in the system, particularly the African countries, who have achieved such low rates of trade growth in recent years. It may be the case that these countries will witness a resurgence of performance over the next 10 to 15 years, and activist intervention to promote their trade will not be necessary, but efforts thus far through regional and other incentives have been largely unsuccessful. Some new direction will likely be needed.

Finally, the policy framework underlying the global economy is undergoing change and will 
continue to do so. A new WTO trade negotiating Round seems imminent. Less can probably be expected of barrier reductions, and more emphasis may need to be placed on avoiding barrier increases. The linkage of trade to other areas through broadened negotiations, as well as attempts to redefine and refocus global institutions could all be major elements of debate. Developing countries need to understand these developments, be ahead and not behind of them, identify areas of key interest and help shape more forcefully than has been the case in the past the global trade structure which emerges for the decades ahead and their development yet to be achieved.

It is fashionable in trade policy circles to argue that the developing country global strategy of the 1970's represented by special and differential treatment broke down in the 1990's, as countries began to pursue individual country interest and adopted outward oriented trade driven developmental strategy. Hence, it is argued now that country interest has now superceded bloc wide interest in trade and economic matters more broadly. This may be to a large degree true of the global economy of the mid1990's, and to some degree will remain looking forward over the next two decades. But, this paper also highlights some key underpinnings of developing country pursuit of individual country interest, and in particular the assumption that both the structure of the global economy and its policy framework will both accommodate such a pursuit and will remain largely unchanged. This paper suggests that these assumptions may need to be challenged to some degree by the developing countries. 


\section{References}

Armstrong, H.W. and R. Read (1998). "Trade and Growth in Small States: The Impact of Global Trade Liberalization", The World Economy, Vol. 21, No. 4, June 1998, pp. 563-585.

Bergsten, F. (1997). “Open Regionalism”, The World Economy, Vol. 20, No. 5, August 1997, pp. 545-566.

Blackhurst, R. (1997). "The WTO and The Global Economy", The World Economy, Vol.20, No. 5, August 1997, pp. 527-544.

Feenstra, R. and G. Hanson (1996). "Globalization, Outsourcing, and Wage Inequality", American Economic Review, May, Vol. 86, No. 2, pp. 240-245.

Frankel, J.A.(ed) (1998). The Regionalization of the World Economy, University of Chicago Press, for NBER, Chicago.

GATT (1994). "News of the Uruguay Round of Multilateral Trade Negotiations", Information and Media Relations Division of GATT, April 12th.

Hamilton, C. and J. Whalley (1996). The Trading System After the Uruguay Round, The Institute of International Economics, Washington, D.C.

Kindleberger, C.P. (1975). The World in Depression, 1929-1939, London: Allen Lane Penguin Press.

Kreuger, A.O. (1998) "Whither the World Bank and the IMF?" Journal of Economic Literature, December, Vol. XXXVI, pp.1983-2020.

Laird, S. (1998). "Multilateral Approaches to Market Access Negotiations", paper prepared for a conference on Multilateral and Regional Trade Agreements: An Analysis of Current Trade Policy Issues, organized by the OAS, WTO, and Georgetown University, and held in Washington, D.C. May 26-27, 1998.

Martin, W. and A. Winters (ed) (1995). The Uruguay Round and The Developing Countries, World Bank Discussion Paper No. 307, World Bank, Washington, D.C.

Michaelopoulos, C. (1998). "The Developing Countries in the WTO" (mimeo) and forthcoming in The World Economy.

Mwega, F.M. and K.L. Muga (1998). "Africa and the World Trading System: A Case Study of Kenya", paper presented to an AERC Workshop, Mombasa, Kenya, April 26-29, 1998. 
Perroni, C. and J. Whalley (1996). "How Severe is Global Retaliation Risk Under Increasing Regionalism?", American Economic Reviews (Papers and Proceedings), May 1996, Vol. 86, No. 2, pp. 57-61.

Perroni, C. and J. Whalley (1998). “The New Regionalism: Trade Liberalization or Insurance?”, Canadian Journal of Economics, to appear.

Piggott, J.R., J. Whalley, and R.M. Wigle (1992)"International Linkages and Carbon Reduction Initiatives" in K. Anderson and R. Blackhurst (eds.), The Greening of World Trade Issues.

Rodrick, D. (1998). "Globalization, Social Conflict and Economic Growth", The World Economy, Vol. 21, No. 2, March 1998, pp. 143-158.

Schott, J.J. (Ed) (1998). Launching New Global Trade Talks: An Action Agenda, Institute fore International Economics, Washington, D.C. Special Report No. 112.

Spinager, D. (1998a). "Textiles Beyond the MFA Phase Out", paper presented to a conference in honour of the $50^{\text {th }}$ Anniversary of GATT/WTO, Warwick University, UK, July $7-10^{\text {th }}$, 1996.

Spinager, D. (1998b). "Background Statistics of Anti Dumping Measures", paper presented at a meeting of an Ad Hoc Expert Group of the Secretary General of UNCTAD on Preparing for Future Multilateral Negotiations, Geneva, September 21-22, 1998.

Thomas, H. and J. Whalley (1998). Uruguay Round Results and the Emerging Trade Agenda, UNCTAD.

Tussie, D. (1998). "Argentina and the WTO: As Good As It Gets", paper presented at a meeting of an Ad Hoc Expert Group of the Secretary General of UNCTAD on Preparing for Future Multilateral Negotiations, Geneva, September 21-22, 1998.

Uimonen, P. and J. Whalley (1997). Environmental Issues in the New World Trading System, MacMillan, London.

UNCTAD (1997a). Handbook of International Trade and Development Statistics, 1995, New York and Geneva.

UNCTAD (1997b). World Investment Report, 1997, Transnational Corporations, Market Structure, and Competition Policy.

Whalley, J. (1989). The Uruguay Round and Beyond: Developing Countries in the Global Trading System, MacMillan, London. 
Whalley, J. (1990). "Special and Differential Treatment for Developing Countries in the Uruguay Round", Economic Journal, Vol.100, No.403, pp.1318-1328.

Whalley, J. (1996). "Trade and Environment Beyond Singapore”, National Bureau of Economic Research Working Paper No. 5768, September 1996.

Whalley, J. (1998). "The Architecture of a New Millennium Round" Paper presented to a conference on the $50^{\text {th }}$ Anniversary of the GATT/WTO at Warwick University, July, 1998, and to appear in The World Economy.

WTO (1998). World Trade Organization Annual Report, 1997, Geneva.

WTO (1998). Electronic Commerce and the Role of the WTO, 1998, Geneva.

World Tourism Organization (1996). Compendium of Tourism Statistics, 1990-94, Sixteenth Edition, Madrid.

Yeats, A. (1994). "A Quantitative Assessment of the Uruguay Round's Effects and Their Implications for Developing Countries", Washington, D.C., World Bank PRE Working Papers Series, processed. 